\title{
Diversity of Zooplanktons and Their Seasonal Variation of Density in Gulabsagar Water Body, Jodhpur (Rajasthan) During 2014-2016
}

\author{
${ }^{1}$ Dr. Naresh Vyas, ${ }^{2}$ Ms. Beena Chouhan \\ ${ }^{1}$ Professor, Department of Zoology, JaiNarain Vyas University, Jodhpur \\ ${ }^{2}$ Research Scholar, Department of Zoology, Jai Narain Vyas University, Jodhpur
}

\begin{abstract}
The present paper deals with the study of diversity of Zooplanktons and their seasonal variation of density in the GulabSagar water body, Jodhpur. Samples were collected for a period of two years (May 2014April 2016) at each month and collected samples were evaluated for the study of Zooplankton. In the present study the zooplanktons consisted of Rotifers, Ostracods, Cladocerans and Copepoda. The quantitative estimation shows that in both the yearsof study (2014 - 2015 and 2015 - 16) the Rotiferans dominated in the population while other wereencountered with moderate number.The study also reveals that during seasonal variation the Rotiferans dominated mainly in the winter season in both the years of study which can be due to favourable temperature and availability of abundance of food material. In the present study the Zooplanktons were represented by 41 species and consisted of Rotifera (15), Cladocera (21), Copepoda ( 4 ) and ostracoda ( 1). The quantitative relationship among different groups of Zooplanktons during year (2014 - 2015) was Rotifera>Copepoda>Cladocera>Ostracoda. During the year $(2015$ - 2016) the above relationship was Rotifera $>$ Copepoda $>$ Cladocera $>$ Ostracoda.
\end{abstract}

Keywords: GulabSagar water lake, Zooplankton, Rotifera, Cladocera, Copepoda, Ostracoda.

\section{INTRODUCTION}

Biodiversity is a variety of life which includes different genes, species, communities and ecosystems. Rich diversity of organisms in an aquatic ecosystem reflects good water quality and any change in water quality due to the addition of pollutants affects diversity and abundance of organisms. Biological parameters includes collection, preservation, identification, qualitative and quantitative enumeration of Zooplankton.

Zooplankton are animals suspended in water with limited of locomotion .They graze heavily on algae, bacteria and suspended detritus. The Zooplanktons are microscopic free living organisms which occupy a central position between the autotrophs and other heterotrophs and form an important link in aquatic food webs. They constitute an important component of secondary production in aquatic ecosystems and play a vital role in the energy allocation in different trophic levels. The knowledge of their seasonal qualitative and qualitative estimation has been considered essential for proper manipulation of the factors influencing biological productivity of the water body.

\section{STUdy AREA}

Jodhpur district is situated between 25051'08" \& 27037'09" North latitude and 71048'09" \& 73052 '06" East longitude covering geographical area of $22,850 \mathrm{sq} \mathrm{km}$. This district comes under arid zone of the Rajasthan State. Jodhpur district is part of Jodhpur Division. The district is divided into 5 sub-divisions namely Jodhpur, Shergarh, Pipar City, Osian \& Phalodi and comprises of 07 tehsils \& 09 blocks. Total number of villages in the district is 1157 .GulabSagar Lake is located about $6 \mathrm{kms}$ from Jodhpur city center near Sardar Market in old city area (23003' and 30012' N latitude and 69039' and $78007^{\prime} \mathrm{E}$ longitude). Measuring $150 \times 90 \mathrm{~m}$ in size with the capacity of $4.48 \mathrm{~m}$ cusecs of water. GulabSagar Lake is actually a water storage constructed in 1788 by Gulab Rai, the mistress of Maharaja Vijay Singh. Earlier the place was occupied with another water source called 'Bawri', which was converted into Gulab Sagar. It took around 8 years for completing the construction of Gulab Sagar. The lake gets water through a canal from Bal Samand Lake (Fig.1). 


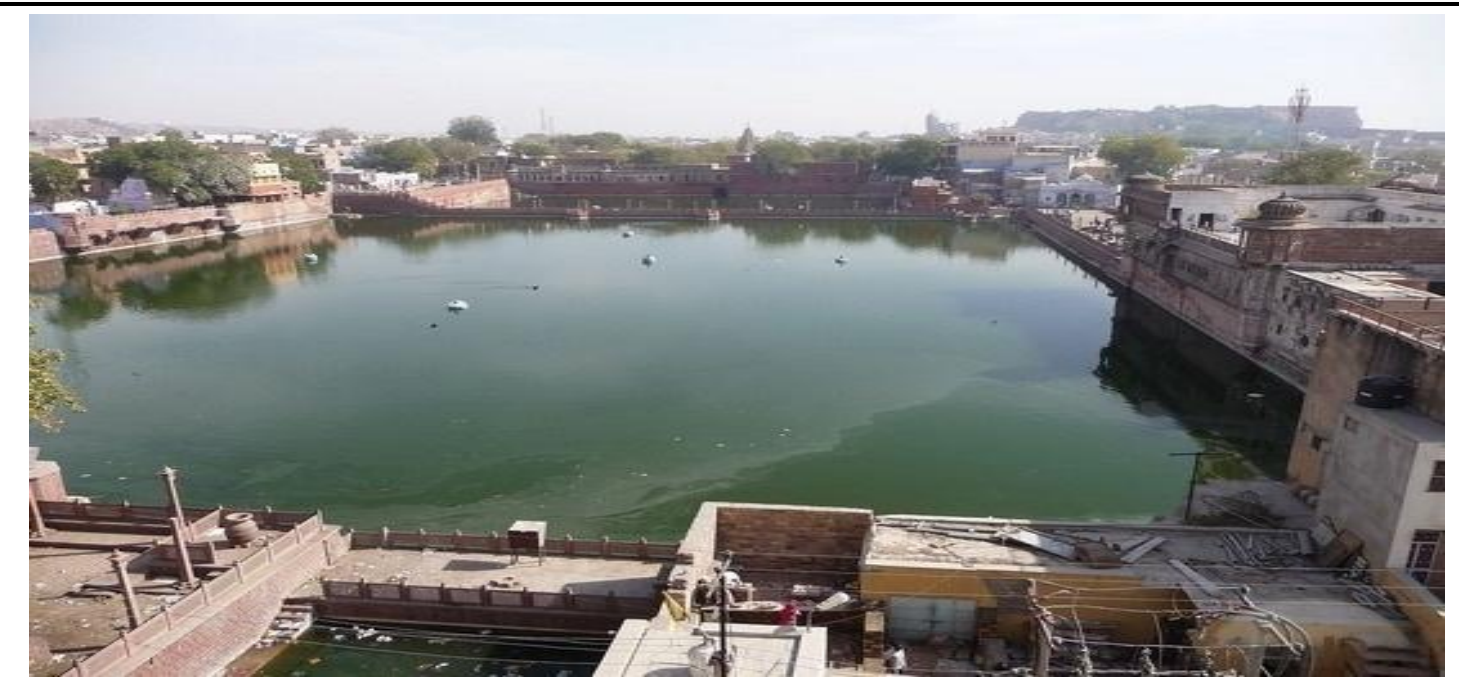

Fig1. Gulab Sagar Lake of Jodhpur

\section{ANAlysis OF WATER SAMPLE}

Water samples were collected in polythene bottles of two litres capacity once in a month, from the different sites of GulabSagar water body for a period of two years (May 2014 to April 2016). These collected samples were than preserved in Refrigerator and Analysis of water was done. The recorded data was divided into mainly three seasons:

1. Summer season (February to May)

2. Monsoon season (June to September)

3. Winter season (October to January)

\section{Materials AND Methods}

Zooplankton collection was done by filtering 100 litres of water sample through Plankton net number 25 made up of Nylon bolting silk cloth having small mesh size approximately $64 \mu$ at monthly intervals, during the period of investigation .These Zooplankton samples were collected in $50 \mathrm{ml}$ bottle and preserved in $4 \%$ formalin.

Quantitatively Zooplanktons were enumerated by Sedgwick Rafter Cell method and results were expressed as :

$$
\text { No. of Zooplankton / ltr. }=(\text { A } \times 1000) \times C / V
$$

Where ,
$\mathrm{A}=$ No. of Zooplankton in $1 \mathrm{ml}$. of sample.
$\mathrm{C}=$ Volume of concentrate in $\mathrm{ml}$.
$\mathrm{V}=$ Volume of sample filter in litre.

\section{RESUlT AND DiSCUSSION}

In the present study the zooplanktons consisted of Rotifers, Ostracods, Cladocerans and Copepoda. The quantitative estimation shows that in both the years of study $(2014-15$ and $2015-16)$ the Rotiferans dominated in the population while other wereen countered with moderate number. The study also reveals that during seasonal variation the Rotiferans dominated mainly in the winter season in both the years of study which can be due to favourable temperature and availability of abundance of food material. The Ostracoda was dominated during summer in both the years of study. The Cladocerans were found more in winter season. They also play an important role in the benthic dynamics.

In the present study the Copepods were maximum during summer season in both the years of study. In the present study the Zooplanktons were represented by 41 species and consisted of Rotifera (15), Cladocera (21), Copepoda (4) and ostracoda (1). The quantitative relationship among different groups of Zooplanktons during year (2014 - 2015) was Rotifera>Copepoda>Cladocera>Ostracoda. During 
the year $(2015$ - 2016) the above relationship was Rotifera>Copepoda>Cladocera> Ostracoda. The Rotifera was represented by Brachionus Calyciflorus, B. diversicornis, B .quadridentatus, B .falcatus, B.caudatus, Plationuspatulus, Keratellatropica, Lecanedecipience, L.cornuta, L.ohioensis, L. monostyla, Horellabrehmi, Asplanchnabrightwelli, Trichocerca spp., Testudinellaspp.

The Cladocera was represented by Diaphanosomasarsi, D.senegal, D.excisum, Ceriodaphnia Cornuta, C. laticaudata, C.quadragula, C.pulchella, Bosminalongirostris, Moinamicrura, Macrothrixgeoldii, M.laticornis, Chydorussphaericus, Echiniscatriserialis, E.odiosa, Pluroxusaduncus, Alonarectangularectangula, Alonarectangularichardi, Alonadavidipunctata, Alonella spp., Camptocerus spp., Simocephalus spp.

The Copepoda was represented by Cyclopspp, Mesocyclop spp. Eucyclop spp. and Diaptomusspp. The Ostracoda was represented by only one species of Cypris.

\subsection{Relative Abundance}

The relative data of Zooplankton were shown in Tables1,2,3,4 and Graph1,2.

The Zooplanktons consisted of Rotifers, Ostracods, Cladocerans and Copepods. Total 730 Ind/1 Zooplanktons were recorded during the year 2014 - 2015 and $844 \mathrm{Ind} / \mathrm{l}$ in the year 2015 -2016. In the Rotifera among the different species during the year 2014 - 2015 Brachionusfalcatus (55 Ind/l) dominated, followed by Keratellatropica (43Ind/l), Asplanchnabrightwelli (22 Ind/l) and Horellabrehmi (2 Ind/l).

During the year 2015 -2016, B. falcatus (101 Ind/l) was dominated, followed by B. calyciflorus (57Ind/l), B. diversicornis (14 Ind/l), Lecanemonostyla (14 Ind/l) and the least appearance was shown by Lecaneohioensis ( 2 Ind/l)

During the year $2014-2015$ the total number of Ostarcoda was recorded as $75 \mathrm{Ind} / \mathrm{l}$ which contributed $10 \%$ where as during the year 2015 -2016 it was recorded 94 Ind/l contributing 11\% of Zooplanktons.

During the year 2014 -2015 Cladocera was recorded as 199Ind/l contributing 21\% and during the year $2015-2016$ as 209 Ind/l contributing 25\%. In Cladocera during the year 2014 -2015among different species Moinamicrura (48 Ind/l) has shown its dominance followed by Ceriodaphniacornuta (38 Ind/l), Alonadavidipunctata (24Ind/l) and the least appearance was shown by Echiniscaodiosa (1Ind/1). During the year 2015 -2016 again Moinamicrura (43 Ind/1) shown its dominance followed by C. cornuta (39 Ind/l), Diaphanosomasenegal (30 Ind/l) and the least appearance was shown by Alonellaspp (1 Ind/l) and Echiniscaodiosa (1 Ind/l).

During the year 2014 -2015, Copepoda was recorded with 224 Ind/l that contribute to $32 \%$ and during the year 2015 -2016 with 257 Ind/l that contributed to 33\% of the total Zooplankton. In Copepoda among the different species during the year 2014-2015 Diaptomus spp. (99 Ind/l) was dominant and the least appearance was shown by Eucyclop spp. (15Ind/l) During the year2015 -2016, Cyclop spp. (66 Ind/l), Eucyclop spp. (66 Ind/l) showed their dominance followed by Mesocyclop spp. (63 Ind/l) and Diaptomus spp. (62 Ind/l).

\subsection{Seasonal Abundance}

The maximum number of Zooplanktons were recorded with $396 \mathrm{Ind} / \mathrm{l}$ during the winter season of the year 2014-2015 and minimum 93 Ind/l in monsoon during the year 2015 -2016.During the monsoon season of the year 2014 -2015, Rotifera contributed 39\%, Ostracoda 19\%, Cladocera 10\% and Copepoda 32\% where as during the year 2015 -2016, Rotifera contributed 30\%, Ostracoda 23\%, Cladocera $14 \%$ and Copepoda $33 \%$.

During the winter season of the year $2014-2015$, Rotifera contributed 39\%, Ostracoda 0\%, Cladocera 43\% and Copepoda 18\% and in the year2015 -2016, Rotifera contributed 40\%, Ostracoda 3\%, Cladocera 36\% and Copepoda 21\%.During the summer season of the year $2014-2015$, Rotifera contributed 23\%, Ostracoda 18\%, Cladocera $17 \%$ and Copepoda $42 \%$ and in the year2015-2016, Rotifera contributed 28\% , Ostracoda 17\%, Cladocera 14\% and Copepoda40\%. Rotiferans were recorded maximum with $157 \mathrm{Ind} / \mathrm{l}$ in the winter season of the year $2014-2015$ and minimum $36 \mathrm{Ind} / \mathrm{l}$ in the monsoon season of the year 2015-2016. It contributed maximum to the extent of $53 \%$ in the winter, followed by $32 \%$ in summer season and $15 \%$ in the monsoon season of the year $2014-2015$.

During the year $2015-2016$, Rotiferansdominated in the winter season by contributing $55 \%$ followed by $32 \%$ in the summer and $13 \%$ in the monsoon. Ostracoda were recorded maximum of $58 \mathrm{Ind} / 1$ in the 


\section{Dr. Naresh Vyas \& Ms. Beena Chouhan}

summer season of the year 2014-2015 and minimum $10 \mathrm{Ind} / \mathrm{l}$ in the winter season of the year 2015 2016. Ostracoda was not recorded in the winter season of the year $2014-2015$. It contributed maximum to the extent of $77 \%$ in the summer season followed by $23 \%$ in the monsoon season of the year $2014-2015$.

During the year $2015-2016$ it dominated with $60 \%$ in the summer season followed by $30 \%$ in the monsoon season and $10 \%$ in thr winter season. Cledocera were recorded with maximum of $144 \mathrm{Ind} / \mathrm{l}$ in the winter season of the year 2014 -2015 and minimum $10 \mathrm{Ind} / \mathrm{l}$ in the monsoon season of the year 2015 -2016. It contributed maximum of $69 \%$ in the winter season, followed by $26 \%$ in the summer season and 5\% in the monsoon season of the year $2014-2015$. During the year $2015-2016$, it was dominated with $69 \%$ in the winter season, followed by $22 \%$ in the summer season and $9 \%$ in the monsoon season.

Copepoda were recorded maximum of $135 \mathrm{Ind} / \mathrm{l}$ in the summer season of the year $2014-2015$ and minimum of 30Ind/l in the monsoon season of the same year. It contributed maximum of $60 \%$ in the summer season, followed by $26 \%$ in the winter season and $14 \%$ in the monsoon season. During the year $2015-2016$ it was dominated with 51\% in the summer season, followed by $33 \%$ in the winter season and $16 \%$ in the monsoon season.

Table1. Monthly variation of Zooplankton at GulabSagar water body, Jodhpur during year 2014-2015

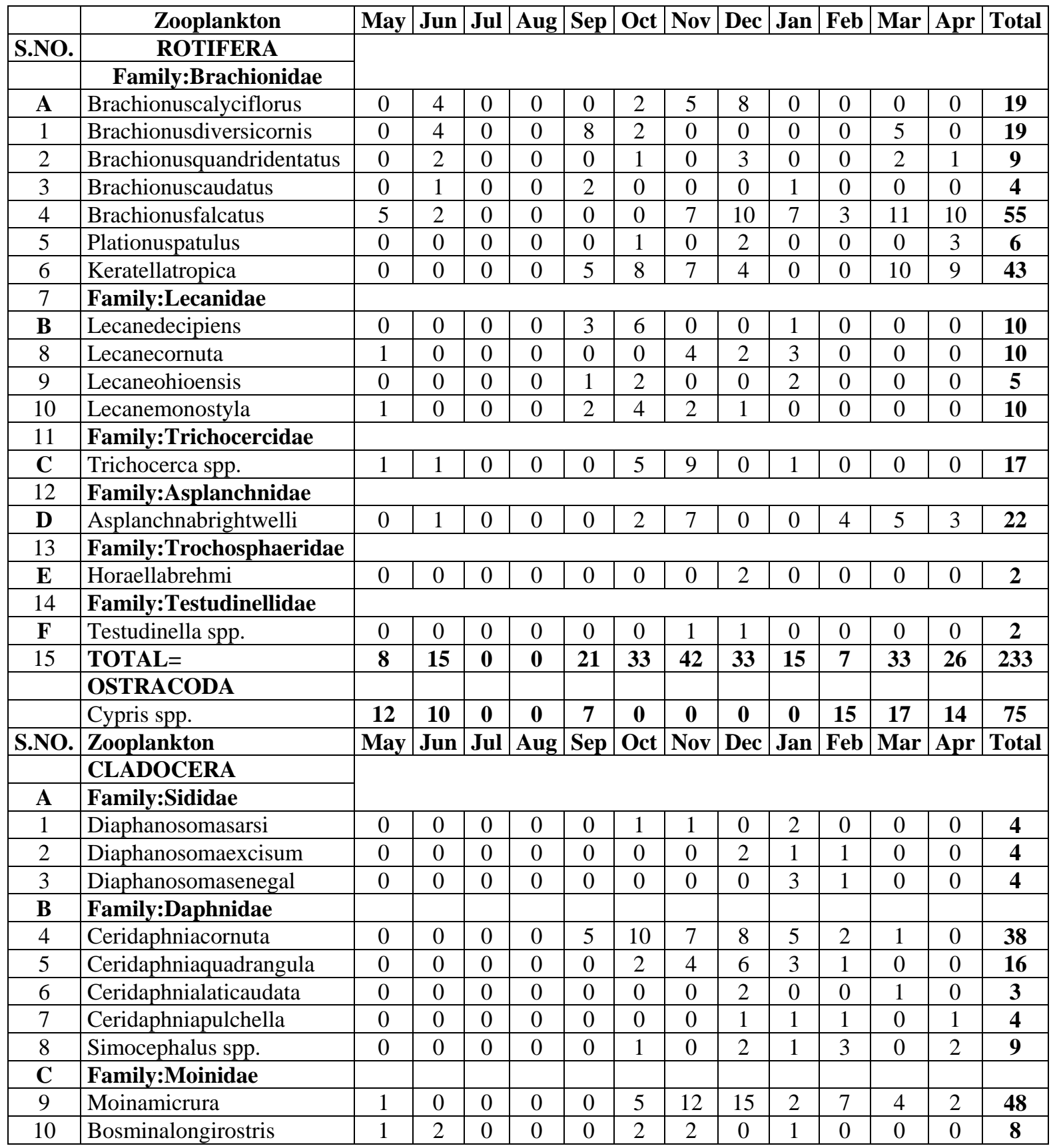


Diversity of Zooplanktons and their Seasonal Variation of Density in Gulabsagar Water Body, Jodhpur (Rajasthan) During 2014-2016

\begin{tabular}{|c|l|c|c|c|c|c|c|c|c|c|c|c|c|c|}
\hline \hline D & Family:Macrothricidae & & & & & & & & & & & & & \\
\hline 11 & Macrothrixgoeldii & 0 & 0 & 0 & 0 & 0 & 2 & 2 & 1 & 2 & 1 & 0 & 0 & $\mathbf{8}$ \\
\hline 12 & Macrothrixlaticornis & 0 & 0 & 0 & 0 & 0 & 1 & 1 & 1 & 2 & 0 & 0 & 0 & $\mathbf{5}$ \\
\hline 13 & Echiniscatriserialis & 0 & 0 & 0 & 0 & 0 & 0 & 1 & 0 & 1 & 0 & 0 & 0 & $\mathbf{2}$ \\
\hline 14 & Echiniscaodiosa & 0 & 0 & 0 & 0 & 0 & 0 & 0 & 1 & 0 & 0 & 0 & 0 & $\mathbf{1}$ \\
\hline E & Family:Chydoridae & & & & & & & & & & & & & \\
\hline 15 & Chydorussphaearicus & 0 & 1 & 0 & 0 & 0 & 0 & 1 & 0 & 0 & 2 & 5 & 2 & $\mathbf{1 1}$ \\
\hline 16 & Pluroxusaduncus & 0 & 0 & 0 & 0 & 0 & 0 & 0 & 1 & 0 & 0 & 0 & 0 & $\mathbf{1}$ \\
\hline 17 & Alonella spp. & 0 & 0 & 0 & 0 & 0 & 0 & 0 & 0 & 0 & 0 & 0 & 0 & $\mathbf{0}$ \\
\hline 18 & Alonarectangularectangula & 0 & 0 & 0 & 0 & 0 & 0 & 1 & 2 & 2 & 0 & 0 & 0 & $\mathbf{5}$ \\
\hline 19 & Alonarectangularichardi & 0 & 0 & 0 & 0 & 0 & 0 & 0 & 0 & 1 & 0 & 2 & 1 & $\mathbf{4}$ \\
\hline 20 & Alonadavidipunctata & 0 & 0 & 0 & 0 & 2 & 0 & 2 & 5 & 6 & 7 & 0 & 2 & $\mathbf{2 4}$ \\
\hline 21 & Camptocercus spp. & 0 & 0 & 0 & 0 & 0 & 0 & 0 & 0 & 0 & 0 & 0 & 0 & $\mathbf{0}$ \\
\hline & TOTAL= & $\mathbf{2}$ & $\mathbf{3}$ & $\mathbf{0}$ & $\mathbf{0}$ & $\mathbf{7}$ & $\mathbf{2 4}$ & $\mathbf{3 4}$ & $\mathbf{4 7}$ & $\mathbf{3 3}$ & $\mathbf{2 6}$ & $\mathbf{1 3}$ & $\mathbf{1 0}$ & $\mathbf{1 9 9}$ \\
\hline & COPEPODA & & & & & & & & & & & & & \\
\hline 22 & Mesocyclop spp. & 1 & 5 & 0 & 0 & 2 & 2 & 0 & 0 & 0 & 3 & 2 & 2 & $\mathbf{1 7}$ \\
\hline 23 & Eucyclop spp. & 1 & 2 & 0 & 0 & 5 & 0 & 0 & 0 & 2 & 2 & 2 & 1 & $\mathbf{1 5}$ \\
\hline 24 & Cyclop spp. & 18 & 5 & 0 & 0 & 0 & 7 & 2 & 10 & 5 & 0 & 22 & 24 & $\mathbf{9 3}$ \\
\hline 25 & Diaptomus spp. & 15 & 0 & 0 & 0 & 11 & 8 & 10 & 8 & 5 & 12 & 19 & 11 & $\mathbf{9 9}$ \\
\hline & TOTAL $=$ & $\mathbf{3 5}$ & $\mathbf{1 2}$ & $\mathbf{0}$ & $\mathbf{0}$ & $\mathbf{1 8}$ & $\mathbf{1 7}$ & $\mathbf{1 2}$ & $\mathbf{1 8}$ & $\mathbf{1 2}$ & $\mathbf{1 7}$ & $\mathbf{4 5}$ & $\mathbf{3 8}$ & $\mathbf{2 2 4}$ \\
\hline
\end{tabular}

Table2. Monthly variations of Zooplankton at GulabSagar water body, Jodhpur during year 2015-2016

\begin{tabular}{|c|c|c|c|c|c|c|c|c|c|c|c|c|c|c|}
\hline S.No. & Zooplankton & May & Jun & Jul & Aug & Sep & Oct & Nov & Dec & Jan & Feb & Mar & Apr & Total \\
\hline & ROTIFERA & & & & & & & & & & & & & \\
\hline $\mathbf{A}$ & Family:Brachionidae & & & & & & & & & & & & & \\
\hline 1 & Brachionuscalyciflorus & 0 & 6 & 0 & 0 & 0 & 3 & 12 & 19 & 10 & 5 & 2 & 0 & 57 \\
\hline 2 & Brachionusdiversicornis & 0 & 2 & 0 & 0 & 0 & 5 & 4 & 0 & 2 & 1 & 0 & 0 & 14 \\
\hline 3 & Brachionusquandridentatus & 0 & 1 & 0 & 0 & 3 & 0 & 5 & 3 & 0 & 0 & 1 & 0 & 13 \\
\hline 4 & Brachi & 0 & 0 & 0 & 0 & 2 & 0 & 2 & 0 & 0 & 0 & 0 & 0 & 4 \\
\hline 5 & Brachi & 8 & 2 & 0 & 0 & 1 & 2 & 5 & 10 & 19 & 25 & 17 & 12 & 101 \\
\hline 6 & Plationt & 1 & 0 & 0 & 0 & 0 & 0 & 1 & 2 & 0 & 0 & 2 & 0 & 6 \\
\hline 7 & Kerate & 0 & 0 & 0 & 0 & 0 & 4 & 0 & 7 & 0 & 0 & 0 & 0 & 11 \\
\hline B & Fam & & & & & & & & & & & & & \\
\hline 8 & Lec & 1 & 0 & 0 & 0 & 0 & 2 & 0 & 4 & 0 & 0 & 0 & 2 & 9 \\
\hline 9 & Leca & 0 & 0 & 0 & 0 & 3 & 6 & 0 & 3 & 2 & 0 & 0 & 0 & 14 \\
\hline 10 & Lec: & 0 & 0 & 0 & 0 & 0 & 0 & 0 & 1 & 1 & 0 & 0 & 0 & 2 \\
\hline 11 & Lecar & 0 & 0 & 0 & 0 & 0 & 2 & 3 & 5 & 1 & 2 & 1 & 0 & 14 \\
\hline $\mathbf{C}$ & Family:Trichocercidae & & & & & & & & & & & & & \\
\hline 12 & Tric & 0 & 1 & 0 & 0 & 0 & 6 & 2 & 0 & 0 & 0 & 0 & 0 & 9 \\
\hline D & Fam & & & & & & & & & & & & & \\
\hline 13 & Aspl & 0 & 1 & 0 & 0 & 15 & 2 & 2 & 0 & 0 & 0 & 10 & 0 & 30 \\
\hline $\mathbf{E}$ & Fam & & & & & & & & & & & & & \\
\hline 14 & Horae & 0 & 0 & 0 & 0 & 0 & 0 & 0 & 0 & 0 & 0 & 0 & 0 & $\mathbf{0}$ \\
\hline $\mathbf{F}$ & Family:Testudinellidae & & & & & & & & & & & & & \\
\hline 15 & & 0 & 0 & 0 & 0 & 0 & 0 & 0 & 0 & 0 & 0 & 0 & 0 & $\mathbf{0}$ \\
\hline & TOT & & 13 & $\mathbf{0}$ & $\mathbf{0}$ & 24 & 32 & 36 & 54 & 35 & 33 & 33 & 14 & 284 \\
\hline & OST1 & & & & & & & & & & & & & \\
\hline & Cypri & & 10 & $\mathbf{0}$ & $\mathbf{0}$ & 18 & 10 & $\mathbf{0}$ & $\mathbf{0}$ & $\mathbf{0}$ & 10 & 15 & 20 & 94 \\
\hline S.NO. & Zoopl & May & Jun & Jul & Aug & Sep & Oct & Nov & Dec & Jan & Feb & Mar & Apr & Total \\
\hline & CLAD & & & & & & & & & & & & & \\
\hline $\mathbf{A}$ & Family:Sididae & & & & & & & & & & & & & \\
\hline 1 & Diaph & 1 & 1 & 0 & 0 & 1 & 4 & 3 & 0 & 0 & 0 & 2 & 2 & 14 \\
\hline 2 & Diaph & 0 & 0 & 0 & 0 & 0 & 0 & 1 & 0 & 0 & 1 & 0 & 0 & 2 \\
\hline 3 & Diaph & 0 & 0 & 0 & 0 & 1 & 2 & 5 & 7 & 8 & 4 & 3 & 0 & 30 \\
\hline B & Fam & & & & & & & & & & & & & \\
\hline 4 & Cerid & 1 & 0 & 0 & 0 & 2 & 8 & 10 & 6 & 5 & 3 & 2 & 2 & 39 \\
\hline 5 & Cerid & 0 & 0 & 0 & 0 & 0 & 3 & 2 & 5 & 1 & 0 & 0 & 0 & 11 \\
\hline 6 & Ceridaphnialaticaudata & 0 & 0 & 0 & 0 & 1 & 0 & 1 & 0 & 0 & 0 & 0 & 0 & 2 \\
\hline 7 & Ceridaphniapulchella & 0 & 1 & 0 & 0 & 2 & 0 & 0 & 3 & 1 & 0 & 0 & 0 & 7 \\
\hline
\end{tabular}


Dr. Naresh Vyas \& Ms. Beena Chouhan

\begin{tabular}{|c|c|c|c|c|c|c|c|c|c|c|c|c|c|c|}
\hline 8 & Simocephalus spp. & 0 & 0 & 0 & 0 & 0 & 0 & 1 & 1 & 0 & 0 & 0 & 0 & 2 \\
\hline $\mathbf{C}$ & Family:Moinidae & & & & & & & & & & & & & \\
\hline 9 & Moinamicrura & 0 & 0 & 0 & 0 & 8 & 10 & 11 & 5 & 0 & 7 & 2 & 0 & 43 \\
\hline 10 & Bosminalongirostris & 0 & 0 & 0 & 0 & 0 & 0 & 1 & 2 & 0 & 0 & 0 & 0 & 3 \\
\hline D & Family:Macrothricidae & & & & & & & & & & & & & \\
\hline 11 & Macrothrixgoeldii & 0 & 0 & 0 & 0 & 0 & 0 & 3 & 0 & 1 & 2 & 0 & 0 & 6 \\
\hline 12 & Macrothrixlaticornis & 0 & 0 & 0 & 0 & 0 & 0 & 0 & 2 & 0 & 2 & 0 & 0 & 4 \\
\hline 13 & Echiniscatriserialis & 0 & 0 & 0 & 0 & 0 & 0 & 0 & 0 & 0 & 0 & 0 & 0 & $\mathbf{0}$ \\
\hline 14 & Echiniscaodiosa & 0 & 0 & 0 & 0 & 0 & 0 & 1 & 0 & 0 & 0 & 0 & 0 & 1 \\
\hline $\mathrm{E}$ & Family:Chydoridae & & & & & & & & & & & & & \\
\hline 15 & Chydorussphaearicus & 2 & 0 & 0 & 0 & 0 & 0 & 2 & 0 & 1 & 3 & 4 & 2 & 14 \\
\hline 16 & Pluroxusaduncus & 0 & 0 & 0 & 0 & 0 & 0 & 0 & 2 & 0 & 0 & 0 & 0 & 2 \\
\hline 17 & Alonella spp. & 0 & 0 & 0 & 0 & 0 & 0 & 0 & 1 & 0 & 0 & 0 & 0 & 1 \\
\hline 18 & Alonarectangularectangula & 0 & 0 & 0 & 0 & 0 & 0 & 2 & 1 & 1 & 2 & 0 & 0 & 6 \\
\hline 19 & Alonarectangularichardi & 0 & 0 & 0 & 0 & 1 & 0 & 2 & 4 & 0 & 0 & 0 & 0 & 7 \\
\hline 20 & Alonadavidipunctata & 0 & 0 & 0 & 0 & 0 & 0 & 2 & 5 & 8 & 0 & 0 & 0 & 15 \\
\hline \multirow[t]{3}{*}{21} & Camptocercus spp. & 0 & 0 & 0 & 0 & 0 & 0 & 0 & 0 & 0 & 0 & 0 & 0 & $\mathbf{0}$ \\
\hline & TOTAL $=$ & 4 & 2 & $\mathbf{0}$ & $\mathbf{0}$ & 16 & 27 & 47 & 44 & 26 & 24 & 13 & 6 & 209 \\
\hline & COPEPODA & & & & & & & & & & & & & \\
\hline 22 & Mesocyclop spp. & 10 & 5 & 0 & 0 & 12 & 5 & 2 & 2 & 4 & 8 & 7 & 8 & 63 \\
\hline 23 & Eucyclop spp. & 8 & 8 & 0 & 0 & 0 & 5 & 6 & 7 & 7 & 8 & 9 & 8 & 66 \\
\hline 24 & Cyclop spp. & 8 & 2 & 0 & 0 & 8 & 6 & 7 & 5 & 5 & 8 & 7 & 10 & 66 \\
\hline \multirow[t]{2}{*}{25} & Diaptomus spp. & 8 & 5 & 0 & 0 & 0 & 5 & 8 & 5 & 6 & 7 & 8 & 10 & 62 \\
\hline & TOTAL $=$ & 34 & 20 & $\mathbf{0}$ & $\mathbf{0}$ & 20 & 21 & 23 & 19 & 22 & 31 & 31 & 36 & 257 \\
\hline
\end{tabular}

Table3. Total number of Zooplankton at GulabSagar water body, Jodhpur during the year 2014-2015

\begin{tabular}{|c|c|c|c|c|c|c|c|c|c|c|c|c|c|c|c|c|}
\hline & \multicolumn{16}{|c|}{ Year 2014-1015 } \\
\hline & \multicolumn{16}{|c|}{ Monthly Seasonal } \\
\hline Zooplankton & May & Jun & July & Aug & Sep & Oct & Nov & Dec & Jan & Feb & Mar & Apr & Mon & Win & Sum & Total \\
\hline Rotifera & 8 & 15 & 0 & 0 & 21 & 33 & 42 & 33 & 15 & 7 & 33 & 26 & 36 & 123 & 74 & 233 \\
\hline ostracoda & 12 & 10 & 0 & 0 & 7 & 0 & 0 & 0 & 0 & 15 & 17 & 14 & 17 & 0 & 58 & 75 \\
\hline Caladocera & 2 & 3 & 0 & 0 & 7 & 24 & 33 & 47 & 33 & 26 & 13 & 10 & 10 & 137 & 51 & 198 \\
\hline Copepoda & 35 & 12 & 0 & 0 & 18 & 17 & 12 & 18 & 12 & 17 & 45 & 38 & 30 & 59 & 135 & 224 \\
\hline Total & 57 & 40 & 0 & 0 & 53 & 74 & 88 & 98 & 60 & 65 & 108 & 88 & 93 & 319 & 318 & 730 \\
\hline
\end{tabular}

Table4. Total number of Zooplankton at GulabSagar water body, Jodhpur during the year 2015-2016

\begin{tabular}{|c|c|c|c|c|c|c|c|c|c|c|c|c|c|c|c|c|}
\hline & \multicolumn{16}{|c|}{ Year 2015-2016 } \\
\hline & \multicolumn{16}{|c|}{ Monthly Seasonal } \\
\hline & May & Jun & July & Aug & Sep & Oct & Nov & Dec & Jan & Feb & Mar & Apr & Mon & Win & Sum & Total \\
\hline Rotifera & 10 & 13 & 0 & 0 & 24 & 32 & 36 & 54 & 35 & 33 & 33 & 14 & 37 & 157 & 90 & 284 \\
\hline ostracoda & 11 & 10 & 0 & 0 & 18 & 10 & 0 & 0 & 0 & 10 & 15 & 20 & 28 & 10 & 56 & 94 \\
\hline Caladocera & 4 & 2 & 0 & 0 & 16 & 27 & 47 & 44 & 26 & 24 & 13 & 6 & 18 & 144 & 47 & 209 \\
\hline Copepoda & 34 & 20 & 0 & 0 & 20 & 21 & 23 & 19 & 22 & 31 & 31 & 36 & 40 & 85 & 132 & 257 \\
\hline Total & 59 & 45 & 0 & 0 & 78 & 90 & 106 & 117 & 83 & 98 & 92 & 76 & 123 & 396 & 325 & 844 \\
\hline
\end{tabular}

\section{Monsoon 2014-2015}

notifera ostracoda Caladocera $\square$ Copepoda

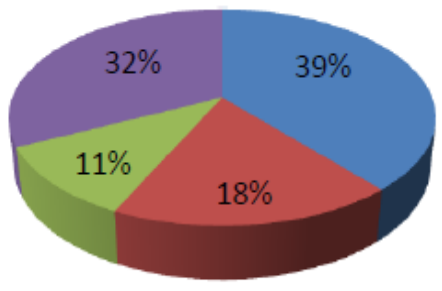

\section{Monsoon 2015-2016}

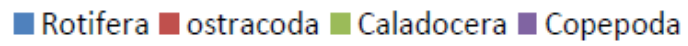

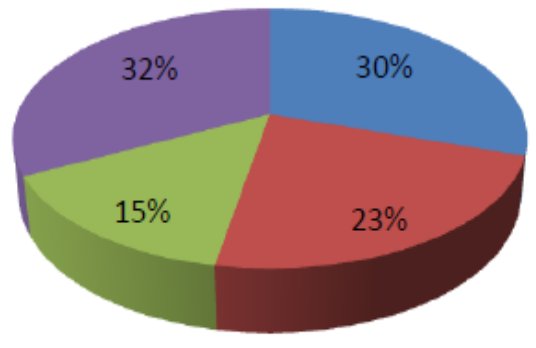




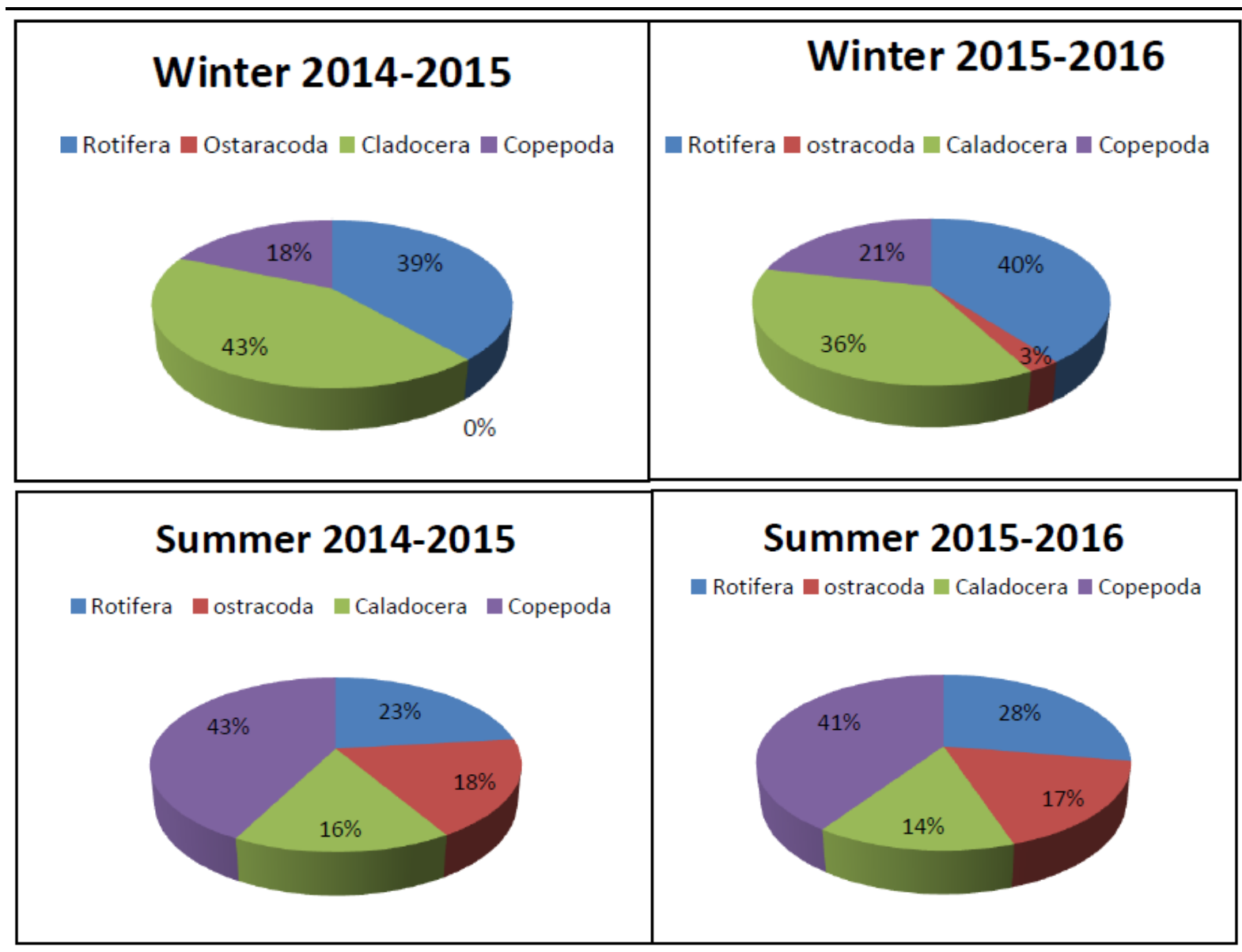

Graph1. Seasonal distribution of Zooplanktons during Monsoon, Winter and Summer Season at GulabSagar water body, Jodhpur

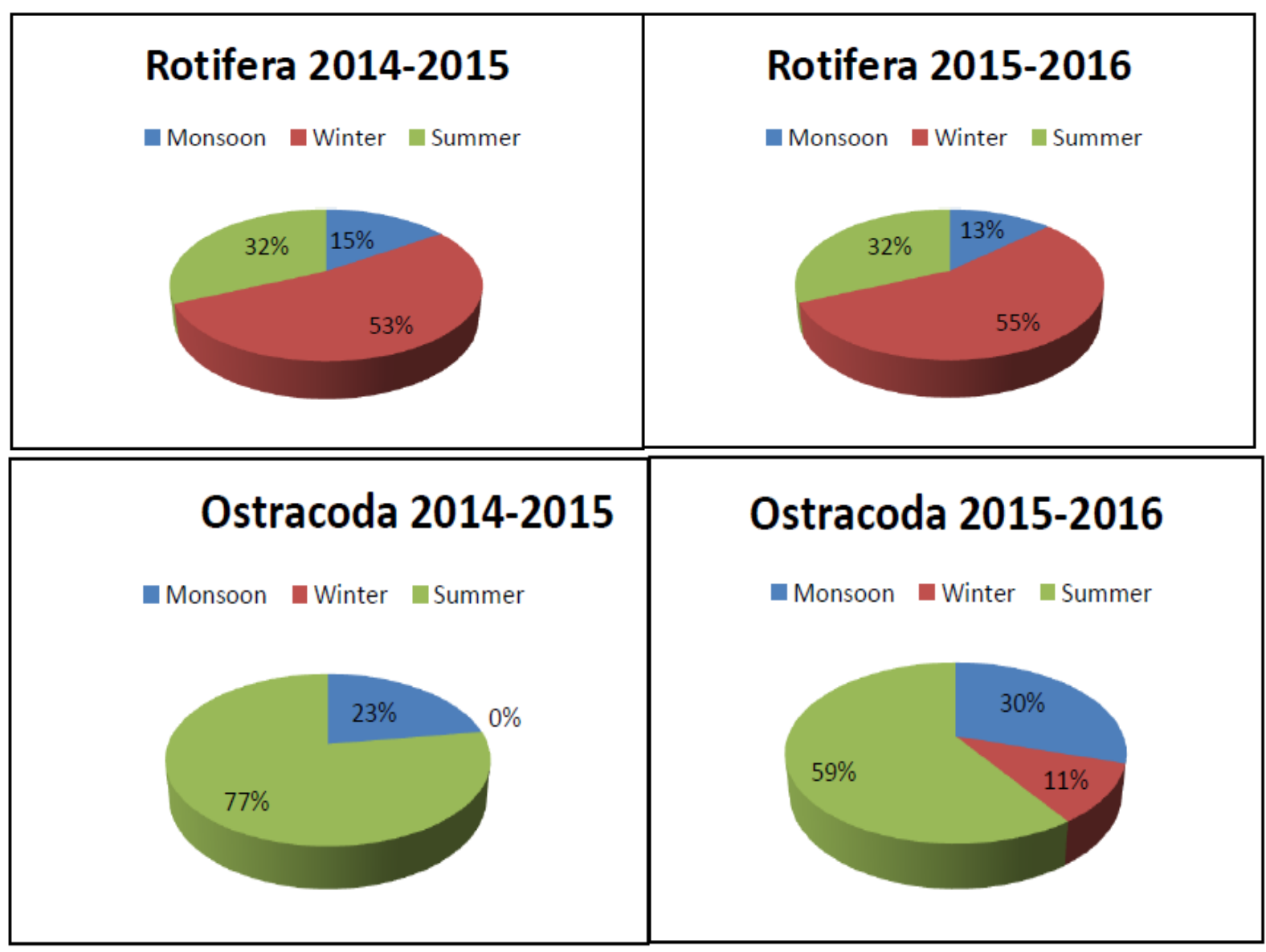




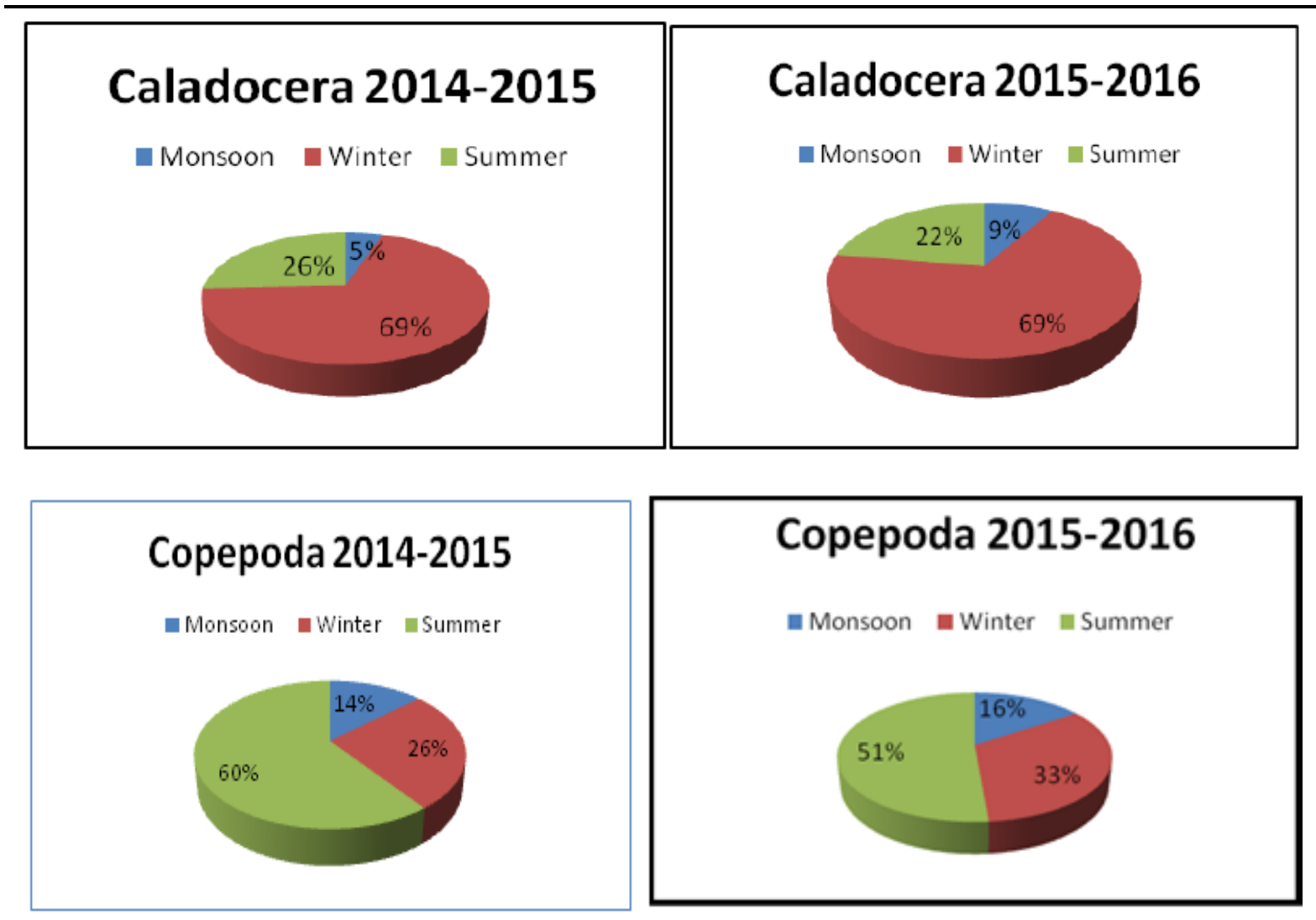

Graph2. Seasonal distribution of Rotifera, Ostracoda, Cladocera and Copepoda at GulabSagar water body, Jodhpur

\section{REFERENCES}

Abbasi, S. A. (1997). Wetlands of India (3) - Wetlands of India: Ecology and threats (3), The Kuttiadi River Basin, Discovery Pub. House, New Delhi, pp. 65-143.

Abdul, A.J. (2002). Evaluation of drinking water quality in Tiruchirapalli. Ind. J. Envir. Health, 44(2): 108-112.

Alam, A. \& Khan, A.A.(1998). On the record of Cladoceran Leydigiaacanthocericoides (Chydoridae) from Aligarh, Uttar Pradesh, India. Journal of Bombay Natural History Society, 95(1): 143-144.

APHA(1985).Standard methods of the examination of water and waste water 16th edn. American Public Health Association, Washington, D.C.

Das, P.K., Micheal, R.G. \& Gupta, A. (1996). Zooplankton community structure of lake Tasek, a tectonic lake in Garo hills, India. Tropical Ecology. 37(2): 257-263.

Haniffa, M. A., Arockiasamy, S. \& Martin, P. (1993). Physico-chemical and microbiological studies in the Perenial River Thabaraparani for the assessment of water quality. Indian J. of Envtl. Prtcn., 13(7): 533-538.

Khan, M.A.\& Rao, I.S.(1981). Zooplankton in the evaluation of pollution, Paper presented at WHO workshop on biological indicators and indices of environmental pollution. Cent.Bd.Prev.Cont.Poll/Osm.Univ, Hyderabad, India.

Kumar, A. Tripathi,S. \&Ghosh, P. (2004). Status of freshwater in 21 century: a review. In Water Pollution: Assessment and Management (Edited by) Arvind Kumar and G. Tripathi. Daya Publishers, Delhi, 520 p 